FIFTY YEARS OF URBAN ACCESSIBILITY:

THE IMPACT OF URBAN RAILWAY NETWORK ON THE LAND GRADIENT IN INDUSTRIALIZING BERLIN

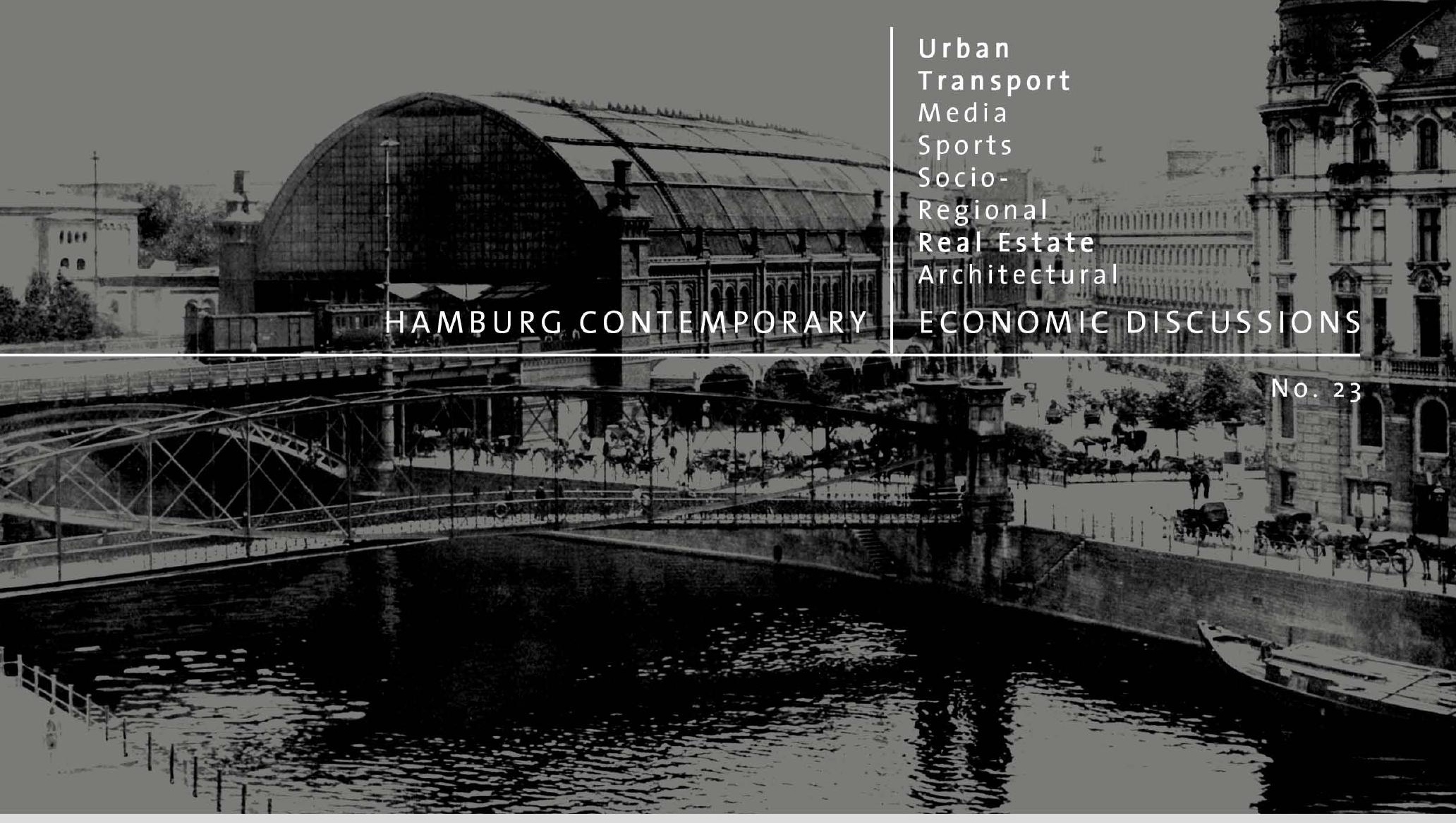


Hamburg Contemporary Economic Discussions

University of Hamburg Faculty Economics and Social Science

Chair for Economic Policy

Von-Melle-Park 5

D-20146 Hamburg | Germany

Tel $+494042838-4622$

Fax $+494042838-6251$

http://www.uni-hamburg.de/economicpolicy

Editor: Wolfgang Maennig

P. Gabriel M. Ahlfeldt

University of Hamburg

Faculty Economics and Social Science

Chair for Economic Policy

Von-Melle-Park 5

D-20146 Hamburg | Germany

Tel $+494042838-5569$

Fax $+494042838-6251$

Nicolai Wendland

ETH Zurich

Swiss Economic Institute

Weinbergstrasse 35

$\mathrm{CH}-8092$ | Zurich

Tel +41 $44632-5344$

wendland@kof.ethz.ch

ISBN 978 - 3- $940369-60$ - 4 (Print)

ISBN $978-3-940369-61-1$ (Online) 


\title{
Fifty Years of Urban Accessibility: The Impact of Urban Railway Network on the Land Gradient in Industrializing Berlin*
}

\begin{abstract}
As the first to use an archival data set on historical land values of Berlin, Germany, from 1890 to 1936 , we exploit exogenous variation in transport technology in order to test the validity of the monocentric city model. Endogenously determining the $C B D$, we conduct cross-section and timedifference analysis and model the land gradient in terms of straight-line distance and travel times. A counterfactual scenario indicates that a large proportion of urban decentralization is attributable to improvements in transport infrastructure. Controlling for spatial dependency, results suggest that the monocentric model fitted the city structure until the mid $20^{\text {th }}$ century.

Keywords: Transport Innovations, Land Values, Location Productivity, Economic History

JEL classification: N7, N9 R33, 012

Version: October 2008
\end{abstract}

\section{Introduction}

The monocentric city is certainly the oldest and probably the most prominent theoretical framework in urban economics. The basic idea is as simple as it is comprehensive. As the city center is the most attractive site for firms and residents, land value decreases as distance, transport cost and travel time to the urban core increase. The model was formalized by ALONSO (1964), MILLS (1969) and MUTH (1969) building on the work of VON THÜNEN (1826). Starting with the pioneering study by MUTH (1969) urban economists have also empirically tested

* We thank, Stephen Redding, Daniel Sturm and Nikolaus Wolf for excellent research environments in Berlin and London. We acknowledge the hospitality of the Centre of Economic Performance at the London School of Economics and Political Science where a considerable part of this research was conducted. We are deeply indebted to Mr. Matschens from the Landesarchiv Berlin who provided us with invaluable material and support. Ahlfeldt also thanks the Swiss Economic Institute of the E.T.H. Zurich for its generous hospitality. 
the negative distance price relationship wherever appropriate data was available. We add to this strand of literature using archival data available for Berlin between 1890 - 1936. We not only test for the cross-sectional relationship between land value and distance to the central business district (CBD), but also examine whether land values over time reacted to variation in transport costs as predicted by the model.

During the second half of the $19^{\text {th }}$ century many cities of the industrialized world experienced major shocks with regards to former transportation systems. Emerging railway networks defined completely new patterns of accessibility and travel behavior. This environment of rapid technological progress offers an ideal playground for testing the monocentric city model using variation in transport costs. Empirical analysis for this period, however, is complicated by scarcity of appropriate data. Effectively, there is still relatively little evidence available using historic land values outside the U.S. or - more precisely - outside Chicago. ${ }^{1}$ The rich body of excellent studies using historical land value data of Chicago is owed to two unique data sources; "100 Years of Land Values", by HOYT (1933) who provides land values on square mile tracks from 1836 to 1928 and "Olcott's Land Values Blue Book of Chicago", presenting annual estimates for land values at block level since the early 1900 s. Aside from these, hardly any comparable data source could be found in the literature. ${ }^{2}$

The archival data for Berlin, Germany, used in this study is available in similar detail in the form of precise city maps (1890-1910) and street indices (1928-1936). After preparing these sources for use in empirical analysis, we are able to add evidence on the evolution of city structure for one of the most important and fastest growing cities of continental Europe during the period of industrialization. Our

Further studies exist for Sydney, New York, and Cleveland.

2 Among the studies using the Hoyt data, KAU \& SIRMANS (1979), MCDONALD \& MCMILLEN (1990), MCMILLEN (1990), MCMILLEN et al. (1992), MCMILLEN (1996), and MILLS (1969) feature most prominently. Data from Olcott's Land Values Blue Book of Chicago" has been used by BEDNARZ (1975), BERRRY (1976), MCDONALD \& BOWMAN (1979), MCDONALD (1981), MCMILLEN (1979), MCDONALD \& MCMILLAN (1990), MCMILLEN \& MCDONALD (1991), MILLS (1969), and YATES (1965). 
study covers the period where the rapid transit network consisting of numerous metrorail and suburban railway lines was largely established as the backbone of urban transport. Besides being the first to collect and use historical land values for Berlin in a broad urban economic analysis, we make use of GIS tools in order to model the evolution of rapid transit network on the basis of historical network plans. Our empirical approach identifies the location of the CBD endogenously so that the center of gravity is allowed to move over time. Spatial autoregressive models are employed to control for omitted variables that are correlated across space.

The remainder of this article is organized as follows. Section 2 presents some historical background and introduces into the data. Cross-sectional gradients referring to distance and travel time to the CBD are estimated and placed into the context of the existing literature in sections 3 and 4. Section 5 provides timedifference estimates used to develop a counterfactual scenario that helps to isolate the impact of rapid transit network as a determinant of urban decentralization. We place our empirical findings into the historical urban context in section 6. The final section concludes.

\section{Historical Background and Data}

\subsection{Industrializing Berlin 1890- 1936}

At the study's starting point Prussia in general and especially Berlin had entered the second phase of industrialization. As is typical for industrializing regions, the revolutionary changes in production technologies generated enormous demand for a labor force, drawing peasants and villagers into the fast-growing cities. The environment of consequently expanding firms and the rapidly increasing demand for space triggered far-reaching processes of decentralization affecting big manufacturers and households simultaneously. The accompanied social, economic, and spatial dynamics sustainably changed the city's inherent structure.

In Berlin, the organically grown CBD had been the center of economic activity for many centuries and was characterized by a dense structure and strict quarter-like 
functional segregation (LEYDEN, 1933). Its specific form allowed for close physical proximity between agents and branches. After the French-Prussian war and the subsequent foundation of the German Reich in 1871, Berlin held the status as the capital for both. This required the building of new administrative entities which were incorporated into the CBD. The growing administrative sector strengthened two effects considerably. Firstly, it contributed to the perceived attractiveness of the area. Firms and service oriented industries like banks and the media were drawn into its proximity with increased physical contact opportunities. Secondly, it generated even more density within both the CBD boundaries and the functionally segregated quarters. This generated even more incentives for agglomeration.

The public railway network further stimulated the reorganization of spatial patterns. In 1877 the circular line, which connected Berlin to its surroundings and to several regional lines, was inaugurated. In 1882 the east-west connection joined several inner city stations with the circular line and up to 1890 a huge area of Berlin and its surroundings was served (BORCHERT et al., 1987). But it was not until the subsequent decades that gradually added stations created a highly developed and very dense network that fundamentally changed the pattern of urban accessibility. While the railway development further stimulated the Prussian economy, it simultaneously served as a means for a constantly migrating work force, which led to a further growing population and an increased density within the inner city. On the other hand, it provided the opportunity for firms and households to settle in geographically less central boroughs and to benefit from lower rents while not losing the privilege of excellent accessibility to the core.

Thus, the gradual displacement of residential areas from the CBD to peripheral areas was facilitated. As a result, strongly localized externalities were amplified by an increasing density of economic activity within the commercialized core region. Owing to ongoing development and expansion processes, by 1910 Berlin was already deeply merged with its surrounding villages. In 1920 the whole area was combined to one administrative unit called Groß-Berlin ('large' Berlin) with 
about 3.9 million inhabitants. By 1936 the number had grown to almost 4.3 million.

\subsection{Land Values}

The geographical framework is defined by a colored map indicating the real land use of a large part of inner Berlin in 1940. It was created by Bruno AUST (1986) and displays the land uses on plot level. Following MCMILLEN's (1996) basic strategy for generating more homogeneity within the sample, we exclusively focus on commercial areas. Restricting our sample to commercial use only also allows for a more precise interpretation of results on the background of the relative theories. All corresponding plots had to be manually extracted and digitized. This procedure allowed for distance calculations and running spatial analyses within standard GIS environments. We obtained 1,718 commercially used plots within a 9 $\mathrm{km}$ radius around the endogenously determined center (see 3 ). These areas set the base for the following process of land value collection.

The land values have been gathered for all extracted plots for 1890, 1896, 1900, 1904, 1910, 1929, and 1936. Since not all plots had been properly developed in all years, some values had eventually been ignored. The whole sample sums up to 11,521 observations. In order to enter the land values, two invaluable sources could be found. The years until 1910 are covered by the technician Gustav MÜLLER (1881-1910). In cooperation with official planning authorities he generated colored maps, providing representative values for the built up blocks of Berlin and its surroundings. If necessary the blocks were even divided into smaller units. The next period was covered by Ferdinand KALWEIT $(1928,1936)$. Owing to WWI and the economic crisis, after Müller he was the first to provide detailed information on land values of Berlin. He received an official assignment and collected the information based on real sales. His data is presented in two books containing all streets and corresponding representative minimum and maximum values within them. The street level generates possible biases when considering the small commercial areas. To overcome this problem, several rules had to be applied. First, it seems plausible that within residentially and commercially used streets, higher rents and therefore higher street values are assigned to the com- 
mercial areas. Second, in some cases the provided values referred to very long road stretches and therefore affected the precision of the data. By consulting the RUNGE (1950) block level map on 1938 land values available for the inner parts of Berlin, careful evaluation allowed for proportionally assigning values to smaller and homogenous street stretches. ${ }^{3}$

To place our project in line with important findings, we shortly summarize used samples. Within the period until 1928 MCMILLEN (1996) uses data from HOYT (1933) on square mile tracts. Between 1836 and 1928 his sample offers a range of 94 to 148 observations. From 1960 to 1990 he concentrates on commercial land values, published in Olcott`s book on land values. The detailed block level allows for 696 to 721 observations each year. SMITH (2003) uses for his survey on Cleveland a random sample on plot sales. It mostly consists of residential areas counting from 61 to 125 observations between 1915 and 1980. The presentation of New York data (ATACK \& MARGO, 1998) is based on the prices of vacant land published in newspapers and provides 72 to 208 observations for the years 1835 to $1900 .{ }^{4}$ The more recent period from 1931 to 1989 covered by ABELSON (1997) is strictly restricted to randomly selected residential areas within Sydney's 22 local government areas. However he provides a total sample ranging from 1,800 to 4,400 observations.

\subsection{Railway Network}

One direct goal of our work is to model travel times to the CBD to be able to infer about the dynamics of land gradient development. We applied three steps to generate intermediate results.

First, we gradually traced back the evolution of the city's complete public railway network including up to 222 stations, over the course of our study period in order

3 Runge covers a considerably smaller area and provides values only for one year in 1938. His values were only consulted to divide big streets into smaller parts and compare them to Kalweit's street level values. They have been ignored in further analyses.

${ }^{4}$ Due to direct taxation on property sales, ATACK \& MARGO (1998) state that published prices may be biased. 
to form digital maps. ${ }^{5}$ Total length of the network in 1936 amounted to more than $410 \mathrm{~km}$. ${ }^{6}$ Almost the same area was connected as in contemporary Berlin, where the network sums up to a total length of $475 \mathrm{~km}$.

Second, adequate velocities had to be developed. Consulting historical network plans, which indicated travel times between stations, allowed for feasibly assuming an average train velocity of $33.8 \mathrm{~km} / \mathrm{h}$ over the complete period. After careful consultation of several historical sources we set the speed of non train-related trips to $1 / 3$ of the train velocity. This assumption should approximately reflect a combined average speed of walking, bus- and streetcar-rides, while at the same time keeping our models as simple and comprehensive as possible. ${ }^{7}$

Third, the actual travel time for all agents within our predefined commercial areas to the endogenously identified CBD had to be calculated by taking into account the abovementioned velocities. Agents are free to choose whether to take a rapid train service or not in order to arrive at the city center. Their decision is solely based on the minimum time spent for the whole trip. If they choose rapid rail transit, their journey consists of a combined network path of a non-train trip to the next station, and a combination of a train ride along the network with a final non-train trip to the city center, which minimizes travel time.

\section{Land Gradient Evolution in International Comparison}

The point of departure for our empirical analysis is the standard monocentric city model in which firms and residents bid higher prices for land closer to the CBD

${ }^{5}$ For all following arguments, relevant information and network plans can be found at http://www.bahnstrecken.de/indexf.htm; http://www.bahnstrecken.de/bse.htm; http://berlineruntergrundbahn.de/; www.stadtschnellbahn-berlin.de; www.berlinerverkehr.de.

6 Network lengths refer to own calculations, based on modeled transport infrstructure.

7 The very dense network of streetcars and buses - even in peripheral areas - suggests relatively high non-train velocities. In 1934, 72 streetcar lines covered $638 \mathrm{~km}$ and bus lines summed up to 343 km (BEIER, 1990; BLEY, 2003; BORCHERT et al., 1987; DITTFURTH, 1993; HOFFMANNAXTHELM, 1982). Since we use straight-line distances and not actual pathways, the velocity may be slightly overestimated. 
due to lower transport costs and travel time savings (ALONSO, 1964; MILLS, 1969; MUTH, 1969). While the early models focused on the trade-off between price of residential land and cost of commuting to an exogenous center, more recent models also offer an explanation for the emergence of central business districts (CBD). Firms, accordingly, have an incentive to move into central agglomerations due to production externalities arising from the spatial interaction between them, which raise productivity and hence the willingness to bid higher prices for land. ${ }^{8}$ Only the need for land keeps the city from collapsing into a single point. Evidence suggesting that land values ( $L V$ ) may be well described by an exponential function of distance to the CBD (distCBD) is available for the cities of Chicago, Cleveland, New York and Sydney (ATACK \& MARGO, 1998; KAU \& SIRMANS, 1979; MCDONALD \& MCMILLEN, 1990; MCMILLEN, 1990, 1996; MCMILLEN, JARMIN, \& THORSNES, 1992; MILLS, 1969; SMITH, 2003). The exponential functional relationship is usually estimated using the well-established log-linear specification.

$\log \left(L V_{i t}\right)=\alpha-\beta \operatorname{distCBD_{it}}+\varepsilon_{i t}$

Parameter $\alpha$ corresponds to the log of land value in the city center while $\beta$ gives the percentage change in land value as one moves $1 \mathrm{~km}$ away from the CBD and $\varepsilon_{i t}$ is an error term satisfying the usual conditions. Most empirical analyses point to land gradients that flat over time, possibly due to changes in the transportation technology, city size or production technology. As we cannot reject that the center of gravity of the city does not also move with time, we replace distCBD by a function of CBD coordinates relative to location $i$ (PLAUT \& PLAUT, 1998).

$\log \left(L V_{t i}\right)=\alpha-\beta\left(\left(X^{C B D}-X_{i t}\right)^{2}+\left(Y^{C B D}-Y_{t i}\right)^{2}\right)^{0.5}+\varepsilon_{t i}$

where $X^{C B D}$ (east/west) and $Y^{C B D}$ (north/south) describe the location of the CBD as coordinates given in units of projected $\mathrm{km}$ and $X_{i}$ and $Y_{i}$ are the same referring to location $i$. Table 1 shows parameter estimates corresponding to equation (2) estimated by the use of non-linear least squares.

${ }^{8}$ See for formal models BORUKHOV \& HOCHMAN (1977), FUJITA \& OGAWA (1982), LUCAS (2001), LUCAS \& ROSSI-HANSBERG (2002), and TEN RAA (1984). 
Tab. 1 Land Gradient 1890 - 1936 (NLS)

\begin{tabular}{|c|c|c|c|c|c|c|c|}
\hline & 1890 & 1896 & 1900 & 1904 & 1910 & 1929 & 1936 \\
\hline$\alpha$ & $\begin{array}{c}6.947 \\
(0.0431)\end{array}$ & $\begin{array}{c}6.846 \\
(0.0281)\end{array}$ & $\begin{array}{l}6.918 \\
(0.028)\end{array}$ & $\begin{array}{l}7.052 " \\
(0.027)\end{array}$ & $\begin{array}{l}7.166 \\
(0.027)\end{array}$ & $\begin{array}{l}6.255^{\prime \prime} \\
(0.044)\end{array}$ & $\begin{array}{c}6.1363 \\
(0.043)\end{array}$ \\
\hline$\beta$ & $\begin{array}{c}0.775 \\
(0.0160)\end{array}$ & $\begin{array}{l}0.583 \\
(0.010)\end{array}$ & $\begin{array}{l}0.520 \\
(0.009)\end{array}$ & $\begin{array}{l}0.509 \\
(0.008)\end{array}$ & $\begin{array}{l}0.453^{\cdots} \\
(0.008)\end{array}$ & $\begin{array}{c}0.4051 \\
(0.012)\end{array}$ & $\begin{array}{c}0.3971 \\
(0.011)\end{array}$ \\
\hline$X^{C B D}$ & $\begin{array}{l}23.860 \\
(0.0035)\end{array}$ & $\begin{array}{l}23.824 \\
(0.0038)\end{array}$ & $\begin{array}{l}23.748 \\
(0.0033)\end{array}$ & $\begin{array}{l}23.697 \\
(0.0033)\end{array}$ & $\begin{array}{l}23.656 \\
(0.0041)\end{array}$ & $\begin{array}{l}23.452 \\
(0.0071)\end{array}$ & $\begin{array}{l}23.420 \\
(0.0059)\end{array}$ \\
\hline$Y^{C B D}$ & $\begin{array}{l}21.022^{* * *} \\
(0.0037)\end{array}$ & $\begin{array}{l}20.781^{* *} \\
(0.0039)\end{array}$ & $\begin{array}{l}20.604 \\
(0.0037)\end{array}$ & $\begin{array}{l}20.614 \\
(0.0037)\end{array}$ & $\begin{array}{l}20.492^{* * *} \\
(0.0036)\end{array}$ & $\begin{array}{l}20.534 \\
(0.0060)\end{array}$ & $\begin{array}{l}20.653 \\
(0.0069)\end{array}$ \\
\hline Obs. & 1,479 & 1,572 & 1,683 & 1,686 & 1,681 & 1,709 & 1,711 \\
\hline $\mathrm{R}^{2}$ & 0.745 & 0.755 & 0.765 & 0.766 & 0.724 & 0.458 & 0.474 \\
\hline
\end{tabular}

Notes: Endogenous variable is log of land value (LV) in RM/sqm in all models. Coordinates refer to the Soldner system by the Senate Department Berlin, whose origin lies south- westward from the boundaries of present Berlin. Standard errors (in parenthesis) are heteroscedasticity robust estimates from separate OLS regression for parameters $\alpha$ and $\beta$, where distance was calculated from estimated CBD coordinates. * denotes significance at the $10 \%$ level, ${ }^{* *}$ denotes significance at the $5 \%$ level and ${ }^{* * *}$ denotes significance at the $1 \%$ level.

According to our estimates, the CBD moved approximately $0.6 \mathrm{~km}$ to the west and $0.4 \mathrm{~km}$ to the south from 1890 to 1936 . Results also suggest a steeply descending land gradient during the period of observation, flattening from a $77.5 \%$ decrease per $\mathrm{km}$ in 1890 to $39.7 \%$ in $1936 .{ }^{9}$ The model fit declines considerably after 1910, indicating either that the monocentric structure of the city was breaking up or that omitted location amenities account for a larger spatial variation in land values. ${ }^{10}$ In case of the latter, there would be a spatial structure within the error term. Since other location factors, despite centrality to the $C B D$, potentially exhibited an influence on land price during the whole study period, a spatial structure in the term is likely to arise. Following the standard procedure, we estimate a spatial error correction model to account for error terms and omitted variables that are correlated across space (ANSELIN, 2003; ANSELIN \& BERA, 1996; ANSELIN \& FLORAX, 1996). ${ }^{11}$ We choose a row-standardized weights matrix $(W)$,

9 Results remain qualitatively unchanged if the 1890 sample is used for all years.

10 Since the data source changes from 1910 to 1929 , there is also the possibility that a higher volatility is attributable to the method of land value assessment.

${ }^{11}$ Another form of spatial dependency emerges from the fact that sales prices are endogenous to neighboring transactions. This dependency can be dealt with by the application of a spatial lag model. Methodological aspects of spatial error and spatial lag models are covered by ANSELIN (1988) and ANSELIN \& BERA (1998). 
where transactions within a distance band of 300 meters are treated as neighbors. ${ }^{12}$ Formally, the spatial autoregressive (SAR) model that we estimate employing a maximum likelihood estimator corrects for the spatial structure of the error term in equation (1) as follows:

$\varepsilon=\lambda W \varepsilon+\mu$,

where, $\mu$ is an independent and identically distributed vector of error terms.

Tab. 2 Land Gradient 1890 - 1936 (SAR)

\begin{tabular}{cccccccc}
\hline \hline & 1890 & 1896 & 1900 & 1904 & 1910 & 1929 & 1936 \\
\hline \multirow{2}{*}{$\alpha$} & $6.156^{\cdots \cdots}$ & $6.339^{\cdots \cdots}$ & $6.747^{\cdots \cdots}$ & $6.860^{\cdots}$ & $7.122^{\cdots}$ & $5.932^{\cdots}$ & $5.893^{\cdots \cdots}$ \\
& $(0.1369)$ & $(0.1019)$ & $(0.0838)$ & $(0.0824)$ & $(0.0824)$ & $(0.1153)$ & $(0.043)$ \\
$\beta$ & $0.565^{\cdots \cdots}$ & $0.540^{\cdots \cdots}$ & $0.546^{\cdots \cdots}$ & $0.532^{\cdots \cdots}$ & $0.519^{\cdots \cdots}$ & $0.386^{\cdots \cdots}$ & $0.383^{\cdots \cdots}$ \\
$\lambda$ & $(0.0003)$ & $(0.0002)$ & $(0.0002)$ & $(0.0002)$ & $(0.0002)$ & $(0.0002)$ & $(0.0002)$ \\
$\lambda$ & $0.883^{\cdots \cdots}$ & $0.891^{\cdots \cdots}$ & $0.853^{\cdots \cdots}$ & $0.848^{\cdots \cdots}$ & $0.833^{\cdots \cdots}$ & $0.839^{\cdots \cdots}$ & $0.816^{\cdots}$ \\
Obs. & 1,479 & 1,572 & 1,683 & 1,686 & 1,681 & 1,709 & 17,11 \\
R $^{2}$ & 0.931 & 0.936 & 0.922 & 0.915 & 0.882 & 0.821 & 0.805 \\
\hline
\end{tabular}

Notes: Endogenous variable is log of land value (LV) in RM/sqm in all models. Standard errors (in parenthesis) are robust for spatial dependency. ${ }^{*}$ denotes significance at the $10 \%$ level, ${ }^{* *}$ denotes significance at the $5 \%$ level and ${ }^{* * *}$ denotes significance at the $1 \%$ level.

The estimated pattern of result is similar to Table 1. Notable differences are a considerably reduced gradient coefficient for 1890 and a smaller increase in the coefficient for 1910. By correcting for spatial correlation the lag-coefficient $\lambda$ also accounts for omitted control variables, which shows in a considerable increase in the coefficient of determination, in particular for the years after 1910. The estimated $R^{2}$ increases from below 0.5 to above 0.8 , leaving gradient estimates almost unchanged. These results indicate that despite an increase in importance of additional location factors, Berlin maintained a basic monocentric structure until at least the mid $20^{\text {th }}$ century. These findings resemble the results provided by MCMILLEN (1996) who found a major decrease in explanatory power of a simple negative exponential power function after 1910. However, employing spatial extension models and locally weighted regressions, results turn out to look more

12 This weights matrix provides the best fit compared to alternative specifications and minimizes the Akaike and Schwarz criteria. 
favorable for the monocentric city model until 1928. Figure 1 highlights that the negative relationship between land value and distance from the center of Berlin remained stable until 1936, although the gradient became flatter and the variance of land values increased.

Fig. $1 \log (L V)$ and Distance from the CBD 1890 and 1936
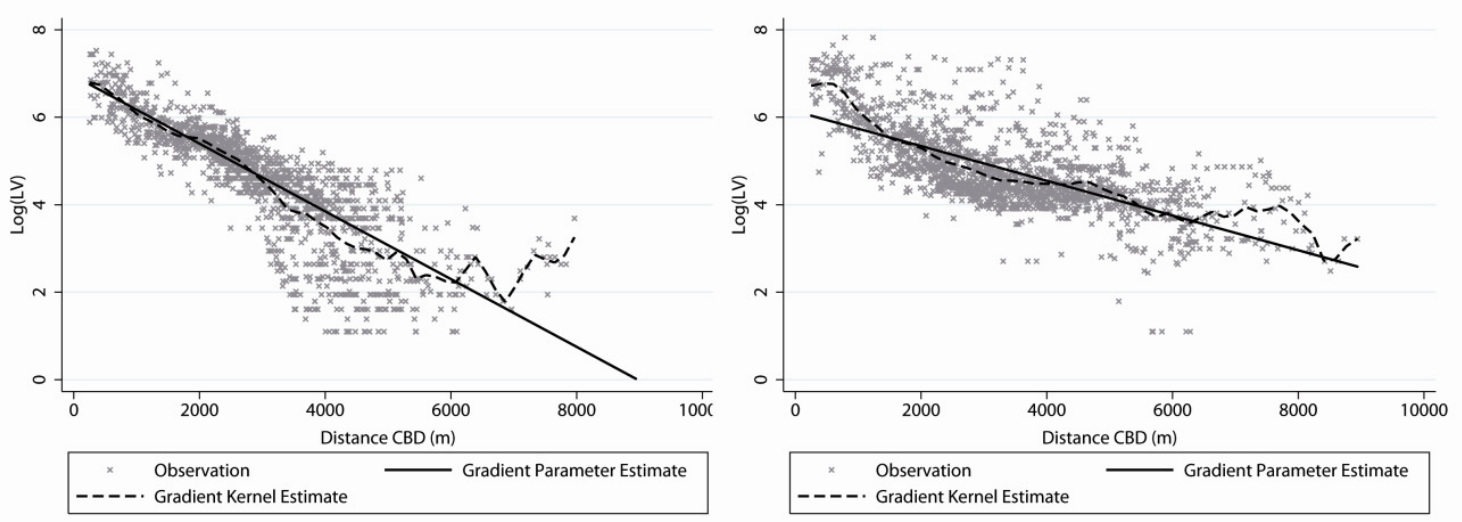

Notes: The left illustration refers to 1890 , the right to 1936 . Parameter estimates refer to Table 1. Kernel regressions of $\log (L V)$ on distCBD use the Epanechnikov function.

In order to allow for heterogeneity in the land gradient we interact distance to the CBD with dummies denoting locations that lie west or south from the estimated gravity center. ${ }^{13}$ Interactives enter equation (1) with a negative sign, revealing whether the land gradient descends more or less steeply to the west and south compared to the east and north. Results presented in Table 3 indicate a significantly smaller gradient decay towards west and south, particularly after 1910. Accordingly, the remarkable decrease in gradient coefficient below the value of 0.5 in 1929 and 1936 (Table 1) is almost entirely attributable to an increase in the valuation of southern and western areas of Berlin. These results are in line with the south-west movement of the city's centre of gravity found in Table 1 as well as with anecdotic historical evidence, which notes a considerable increase in economic wealth in these areas at the beginning of the $20^{\text {th }}$ century (ELKINS \& HOFMEISTER, 1988; HOFMEISTER, 1990; LEYDEN, 1933; LOUIS, 1936). Improvements in transport infrastructure as well as the emergence of a strong sub-center along the Boulevards Kurfürstendamm and Tauentzienstraße may

${ }^{13}$ This approach is alternative to the application of a SAR model since both address spatial variation in land value that is not explained by the simple exponential function. 
also account for these spatial asymmetries and will be addressed in the remainder of this article.

Tab. 3 Heterogeneity in Land Gradients 1890 - 1936 (OLS)

\begin{tabular}{|c|c|c|c|c|c|c|c|}
\hline & 1890 & 1896 & 1900 & 1904 & 1910 & 1929 & 1936 \\
\hline$\alpha$ & $\begin{array}{c}6.947^{* *} \\
(0.0439)\end{array}$ & $\begin{array}{c}6.883^{\cdots *} \\
(0.0336)\end{array}$ & $\begin{array}{c}6.956 \\
(0.0274)\end{array}$ & $\begin{array}{c}7.085^{* *} \\
(0.0268)\end{array}$ & $\begin{array}{c}7.198 \\
(0.0262)\end{array}$ & $\begin{array}{l}6.326 \\
(0.0403\end{array}$ & $\begin{array}{c}6.217^{\cdots *} \\
(0.0385\end{array}$ \\
\hline$\beta$ & $\begin{array}{c}0.778 \\
(0.0195)\end{array}$ & $\begin{array}{c}0.540 \\
(0.0002)\end{array}$ & $\begin{array}{c}0.572 \\
(0.0112)\end{array}$ & $\begin{array}{c}0.556 \\
(0.0108)\end{array}$ & $\begin{array}{l}0.500 \\
(0.0104)\end{array}$ & $\begin{array}{c}0.504 \\
(0.0157)\end{array}$ & $\begin{array}{c}0.503^{\cdots} \\
(0.0153)\end{array}$ \\
\hline $\begin{array}{l}\text { distCBD } \\
\mathrm{x} \text { West } \\
\text { distCBD } \\
\mathrm{x} \text { South }\end{array}$ & $\begin{array}{c}-0.014 \\
(0.0122) \\
-0.019 \\
(0.0125)\end{array}$ & $\begin{array}{c}-0.008 \\
(0.0110) \\
-0.038 \\
(0.0089)\end{array}$ & $\begin{array}{l}-0.010 \\
(0.0072) \\
-0.048 \\
(0.0071)\end{array}$ & $\begin{array}{c}-0.007 \\
(0.0070) \\
-0.046 \\
(0.0069)\end{array}$ & $\begin{array}{c}-0.005 \\
(0.0068) \\
-0.051 \\
(0.0066)\end{array}$ & $\begin{array}{l}-0.034 \\
(0.0102) \\
-0.080 \\
(0.0104)\end{array}$ & $\begin{array}{l}-0.038 \\
(0.0096) \\
-0.080 \\
(0.0102)\end{array}$ \\
\hline $\begin{array}{l}\text { Obs. } \\
\mathrm{R}^{2}\end{array}$ & $\begin{array}{l}1,479 \\
0.746 \\
\end{array}$ & $\begin{array}{l}1,572 \\
0.759 \\
\end{array}$ & $\begin{array}{l}1,683 \\
0.772 \\
\end{array}$ & $\begin{array}{l}1,686 \\
0.773 \\
\end{array}$ & $\begin{array}{l}1,681 \\
0.734 \\
\end{array}$ & $\begin{array}{l}1,709 \\
0.483 \\
\end{array}$ & $\begin{array}{l}1,711 \\
0.500 \\
\end{array}$ \\
\hline
\end{tabular}

Notes: Endogenous variable is log of land value (LV) in RM/sqm in all models. Standard errors (in parenthesis) are heteroscedasticity robust. * denotes significance at the $10 \%$ level, ${ }^{* *}$ denotes significance at the $5 \%$ level and ${ }^{* * *}$ denotes significance at the $1 \%$ level.

In line with the existing evidence for Chicago (MCMILLEN, 1996), Cleveland (SMITH, 2003), New York (ATACK \& MARGO, 1998) and Sydney (ABELSON, 1997) we find a flattening gradient and decreasing coefficients of determination over time, first of all in the OLS estimates. Notably, our estimated decay coefficients are larger compared to previous studies, including MCMILLEN (1996) who also restricted the sample to commercial land values. These large coefficients reflect a very high concentration of economic activity within a relatively small core area. Such a strong agglomeration may result from a production technology that generates highly localized externalities resulting in an incentive for firms to locate closer to each other. Alternatively, very high transport costs could also account for dense concentration. ${ }^{14}$ The latter seems somewhat unlikely since at least by the end of the observation period Berlin possessed a well-developed transport network, which will receive more attention in the following sections. Our results, which are the first available for Europe, are more likely to reflect some kind of historical persistency, which could be typical for relatively old cities. Berlin's cen-

${ }^{14}$ As the strict functional segregation and very high density within the very core remarkably influenced physical proximity (see section 2), we assume that highly localized externalities account for steeper gradients. 
tral business district, even by the end of our observation period, hardly exceeded the boundaries of the historic downtown district established hundreds of years ago, covering an area of not more than $1.5 \mathrm{~km}$ radius (ELKINS \& HOFMEISTER, 1988; LEYDEN, 1933). Table 4 compares the existing international evidence on historical land gradients.

Tab. 4 International Land Gradient Estimates

\begin{tabular}{cccccc}
\hline \hline & Berlin & Chicago $^{*}$ & Cleveland $^{*}$ & New York $^{*}$ & Sydney \\
\hline \multirow{2}{*}{$1835-36$} & & 0.38 & & 0.40 & \\
& & $(0.83)$ & & $(0.72)$ & \\
$1857-60$ & & 0.40 & & 0.19 & \\
& & $(0.84)$ & & $(0.63)$ & \\
$1873-75$ & & 0.30 & & 0.09 & \\
& & $(0.71)$ & & $(0.17)$ & \\
$1890-92$ & 0.78 & 0.31 & & 0.11 & \\
& $(0.75)$ & $(0.58)$ & & $(0.28)$ & \\
1900 & 0.52 & & 0.06 & \\
& $(0.77)$ & & & $(0.01)$ & \\
$1910-15$ & 0.45 & 0.30 & 0.40 & & \\
& $(0.72)$ & $(0.61)$ & $(0.49)$ & & \\
$1928-31$ & 0.41 & 0.12 & 0.27 & & 0.094 \\
& $(0.46)$ & $(0.24)$ & $(0.32)$ & & $0.55)$ \\
$1936-48$ & 0.40 & & 0.30 & & 0.078 \\
& $(0.47)$ & & $(0.49)$ & & $(0.53)$ \\
$1968-70$ & & 0.03 & 0.11 & & 0.032 \\
& & $(0.02)$ & $(0.21)$ & & $(0.28)$ \\
\hline
\end{tabular}

Notes: Coefficients refer to simple negative exponential models estimated in log-linear specification as represented in equation (1). Chicago results are from MCMILLAN (1997) referring to 1836, 1857, 1873, 1892, 1910, 1928, and 1970. Cleveland results are from SMITH (2003) referring to 1915, 1930, 1940 and 1970. New York results are from ATACK \& MARGO (1998) referring to $1835,1860,1875,1890$ and 1900 . The model also includes a control for corner lot. Sydney results are from ABELSON (1997) referring to 1931, 1948, and 1968. Berlin results are taken from Table 1. Coefficients of determination are presented in parenthesis. ${ }^{*}$ Coefficients are rescaled from miles to $\mathrm{km}$.

\section{Travel Time Gradients}

As discussed in section 2, our observation period covers the peak time of industrialization in Berlin, characterized by ongoing city growth, technological progress and major improvements in transport infrastructure. The implementation of rapid transit lines as a means of mass transportation potentially exhibited a major impact on the value of urban land as effective accessibility was reshaped 
along these lines. Figures 2 and 3 illustrate how the monocentric form of CBDaccessibility broke up into a more complex pattern. ${ }^{15}$ Our travel time measure strictly refers to the fastest journey to the CBD whereby residents are allowed to choose whether to use rapid transit lines for a part of the journey or not. Assuming that the use of rapid transit lines in general was affordable (BLEY, 2003) and, hence, opportunity cost of travel time dominated physical distance in terms of perceived accessibility, land values for a given location should essentially depend on the time the journey to the CBD takes.

\section{Fig. 2 Travel Time to CBD 1890}

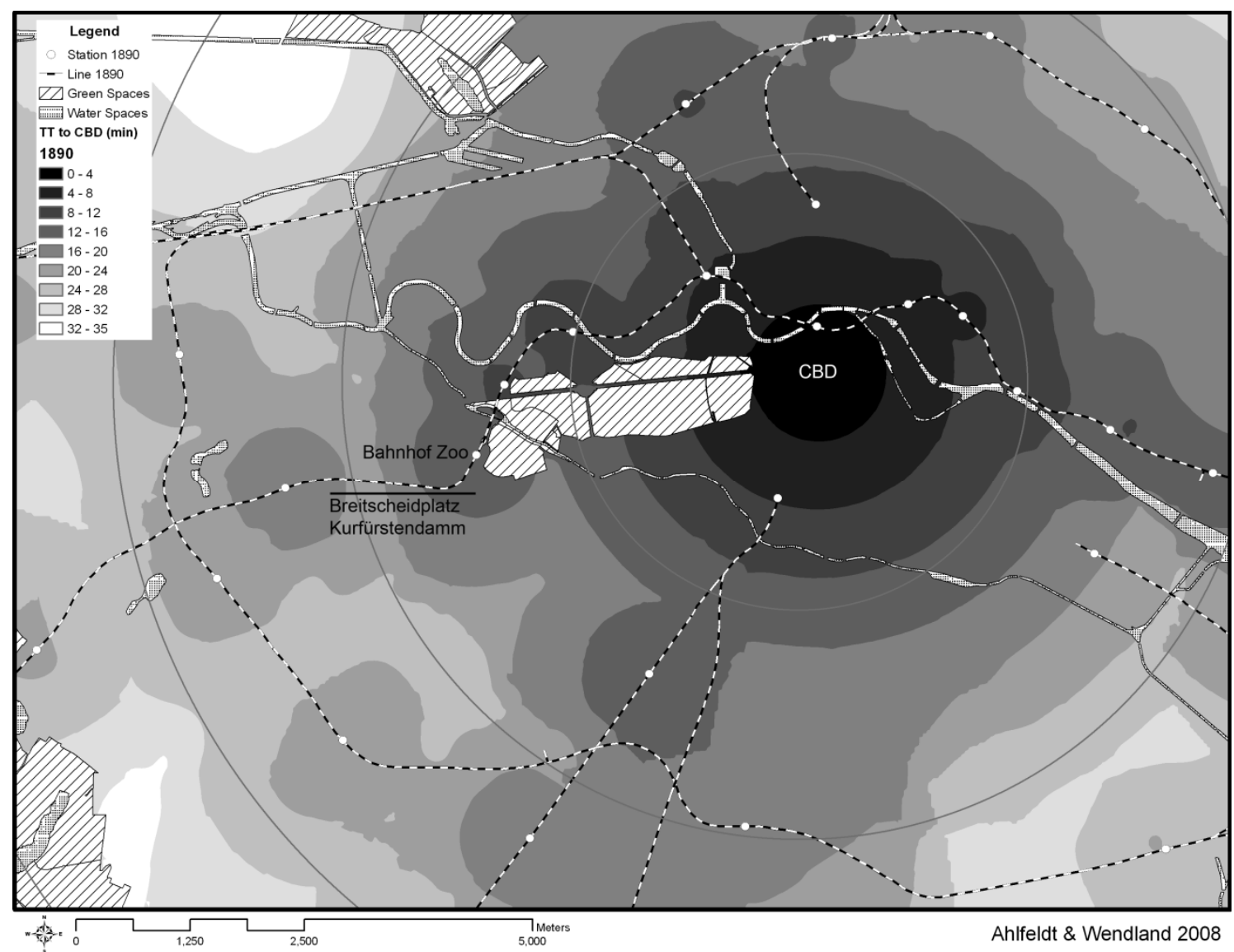

Notes: Map shows spatially interpolated travel times using ordinary kriging with spherical semivariogram model.

Source: Urban and Environmental Information System of the Senate Department Berlin (2006), Network Plans.

${ }^{15} \mathrm{CBD}$ are defined on the basis of Table 1 results. 
Fig. 3 Travel Time to CBD 1936

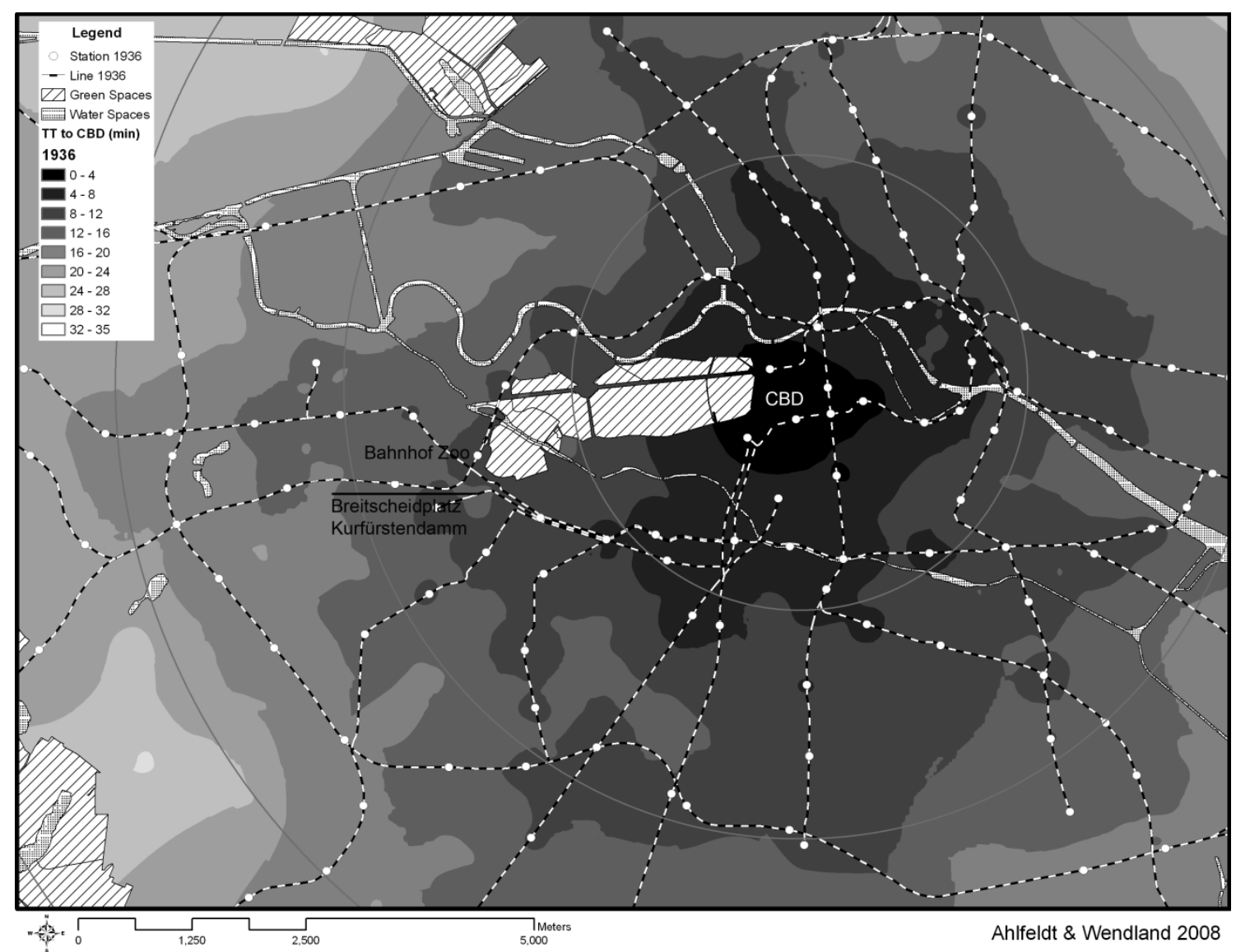

Notes: Map shows spatially interpolated travel times using ordinary kriging with spherical semivariogram model.

Source: Urban and Environmental Information System of the Senate Department Berlin (2006), Network Plans.

In order to account for infrastructural improvements, particularly the implementation of the rapid transit network, we replace straight line distance by travel time in equation (1). Consequently, changes in travel time gradient will not - or at least to a lower degree - be attributable to improvements in transport infrastructure. The other way round, by comparing how distance and time gradients change over time, we may infer about how the inauguration of rapid transit lines changed the pattern of land valuation.

Table 5 and 6 show travel time gradient estimates referring to the location of the CBD as estimated in Table 1 employing OLS and SAR estimators. 
Tab. 5 Travel Time Gradient 1890 - 1936 (OLS)

\begin{tabular}{cccccccc}
\hline \hline & 1890 & 1896 & 1900 & 1904 & 1910 & 1929 & 1936 \\
\hline \multirow{2}{*}{$\alpha$} & $7.047^{\cdots \cdots}$ & 7.096 & $7.056 \cdots$ & $7.234 \cdots$ & $7.231^{\cdots \cdots}$ & $6.624 \cdots$ & $6.489 \cdots$ \\
& $(0.0458)$ & $(0.0398)$ & $(0.0373)$ & $(0.0361)$ & $(0.0371)$ & $(0.0506)$ & $(0.0497)$ \\
$\beta$ & $0.175 \cdots$ & $0.150^{\cdots \cdots}$ & $0.128 \cdots$ & $0.140^{\cdots \cdots}$ & $0.124 \cdots$ & $0.156 \cdots$ & $0.153^{\cdots \cdots}$ \\
& $(0.0034)$ & $(0.0030)$ & $(0.0025)$ & $(0.0027)$ & $(0.0030)$ & $(0.0042)$ & $(0.0041)$ \\
Obs. & 1,479 & 1,572 & 1,683 & 1,686 & 1,681 & 1,709 & 1,711 \\
$R^{2}$ & 0.641 & 0.630 & 0.616 & 0.657 & 0.588 & 0.489 & 0.497 \\
\hline
\end{tabular}

Notes: Endogenous variable is log of land value (LV) in RM/sqm in all models. Standard errors (in parenthesis) are heteroscedasticity robust. * denotes significance at the $10 \%$ level, ${ }^{* *}$ denotes significance at the $5 \%$ level and ${ }^{* * *}$ denotes significance at the $1 \%$ level.

Compared to distance-based estimates represented in Table 1, variation in the gradient coefficient is generally smaller. There is also no clear tendency apparent in the evolution of gradient over time. If any, there is a flattening of the gradient until 1900, which is largely reversed by 1929. These slight changes in travel time gradients may be attributable to changes in the production technology as during the respective period both heavy industry as well as services experienced a boom. As productivity of heavy industry did not essentially depend on proximity to the $\mathrm{CBD}$, the increasing need for land led to an outward movement to the city fringe and a potentially flattening gradient around the turn of the centuries. ${ }^{16}$ The central land which became available was occupied by service industries whose interactions with other economic and government agents were largely based on faceto-face contacts. Corresponding agglomeration economies were therefore highly localized and increased the value of the CBD proximity. The slightly varying travel time gradient coefficients probably reflect the tension between both driving forces.

${ }^{16}$ Local legislation supported the displacement of heavy industry from the urban core due to environmental concerns. 
Tab. 6 Travel Time Gradient 1890 - 1936 (SAR)

\begin{tabular}{|c|c|c|c|c|c|c|c|}
\hline & 1890 & 1896 & 1900 & 1904 & 1910 & 1929 & 1936 \\
\hline$\alpha$ & $\begin{array}{c}5.986 \\
(0.1647)\end{array}$ & $\begin{array}{c}5.088 \\
(0.1492)\end{array}$ & $\begin{array}{c}5.424 \\
(0.1413)\end{array}$ & $\begin{array}{c}5.799 \\
(0.1278)\end{array}$ & $\begin{array}{c}6.091 " ' \\
(0.1263)\end{array}$ & $\begin{array}{c}5.880 \\
(0.1162)\end{array}$ & $\begin{array}{c}5.960 " \\
(0.1056)\end{array}$ \\
\hline$\beta$ & $\begin{array}{c}0.116 \\
(0.0077)\end{array}$ & $\begin{array}{c}0.084 \\
(0.0068)\end{array}$ & $\begin{array}{c}0.083^{*} \\
(0.0065)\end{array}$ & $\begin{array}{c}0.096 \\
(0.0062)\end{array}$ & $\begin{array}{c}0.100 \\
(0.0066)\end{array}$ & $\begin{array}{c}0.116 \\
(0.0076)\end{array}$ & $\begin{array}{c}0.124 \\
(0.0071)\end{array}$ \\
\hline$\lambda$ & $0.908^{\cdots \prime}$ & 0.949 & $0.941^{\cdots}$ & $0.931^{\cdots}$ & $0.922^{* *}$ & $0.842^{\cdots}$ & 0.814 \\
\hline Obs. & 1,479 & 1,572 & 1,683 & 1,686 & 1,681 & 1,709 & 1,711 \\
\hline Ad. $R^{2}$ & 0.931 & 0.934 & 0.919 & 0.914 & 0.880 & 0.821 & 0.805 \\
\hline
\end{tabular}

Notes: Endogenous variable is log of land value (LV) in RM/sqm in all models. Standard errors (in parenthesis) are robust for spatial dependency. ${ }^{*}$ denotes significance at the $10 \%$ level, ${ }^{* *}$ denotes significance at the $5 \%$ level and ${ }^{* * *}$ denotes significance at the $1 \%$ level.

The absence of a clear trend in the travel time gradients together with a continuously decreasing distance gradient suggests that transport innovations essentially promoted the relative increase in the attractiveness of peripheral locations and, hence, the flattening of the land gradient.

Table 7 investigates spatial heterogeneity in travel time gradient employing the same methodology as in Table 3. Results again suggest a significantly flatter gradient decay towards the western and southern parts since 1929. In previous years, the relationship was the other way round. For the south, there is a significantly lower valuation with respect to effective accessibility, where the simple distance measure had suggested the opposite effect (Table 3). A similar, even stronger, switch from a positive to negative sign is found for the western interactive, probably reflecting the emergence of the Kudamm area as a strong subcenter. As is evident from Figure 2, the respective areas, in particular the area around Kurfürstendamm and Bahnhof Zoo, were already well-connected by 1890. After all, development of transport infrastructure apparently preceded the evolution of land values, indicating a casual importance of transport infrastructure for the value of urban land. 
Tab. 7 Heterogeneity in Travel Time Gradients 1890 - 1936 (OLS)

\begin{tabular}{|c|c|c|c|c|c|c|c|}
\hline & 1890 & 1896 & 1900 & 1904 & 1910 & 1929 & 1936 \\
\hline$\alpha$ & $\begin{array}{c}7.018 \\
(0.0450)\end{array}$ & $\begin{array}{c}7.011 \\
(0.0406)\end{array}$ & $\begin{array}{c}7.0799^{\prime \prime} \\
(0.0368)\end{array}$ & $\begin{array}{c}7.283 \\
(0.0318)\end{array}$ & $\begin{array}{c}7.316 \\
(0.0327)\end{array}$ & $\begin{array}{c}6.652 \\
(0.0495)\end{array}$ & $\begin{array}{c}6.527 \\
(0.0493)\end{array}$ \\
\hline$\beta$ & $\begin{array}{c}0.137^{\cdots} \\
(0.0041)\end{array}$ & $\begin{array}{c}0.116 \\
(0.0044)\end{array}$ & $\begin{array}{c}0.114 \\
(0.0036)\end{array}$ & $\begin{array}{c}0.116 \\
(0.0031)\end{array}$ & $\begin{array}{c}0.105 \\
(0.0031)\end{array}$ & $\begin{array}{c}0.171 \\
(0.0047)\end{array}$ & $\begin{array}{c}0.167 \\
(0.0047)\end{array}$ \\
\hline $\begin{array}{c}\text { distCBD } \\
\text { xWest } \\
\text { distCBD } \\
\text { xSouth }\end{array}$ & $\begin{array}{c}0.040 \\
(0.0027) \\
0.015 \\
(0.0028)\end{array}$ & $\begin{array}{c}0.036 \\
(0.0024) \\
0.004 \\
(0.0028)\end{array}$ & $\begin{array}{c}0.027^{* *} \\
(0.0019) \\
-0.0018 \\
(0.0024)\end{array}$ & $\begin{array}{c}0.034 \\
(0.0019) \\
0.009 \\
(0.0021)\end{array}$ & $\begin{array}{c}0.034 \\
(0.0021) \\
0.007 \\
(0.0022)\end{array}$ & $\begin{array}{l}-0.010 \\
(0.0027) \\
-0.008 \\
(0.0031)\end{array}$ & $\begin{array}{c}-0.013 \\
(0.0026) \\
-0.002 \\
(0.0029)\end{array}$ \\
\hline $\begin{array}{l}\text { Obs. } \\
\text { Ad. } R^{2}\end{array}$ & $\begin{array}{l}1,479 \\
0.705\end{array}$ & $\begin{array}{l}1,572 \\
0.683\end{array}$ & $\begin{array}{l}1,683 \\
0.661\end{array}$ & $\begin{array}{l}1,686 \\
0.727\end{array}$ & $\begin{array}{l}1,681 \\
0.662\end{array}$ & $\begin{array}{l}1,709 \\
0.495\end{array}$ & $\begin{array}{l}1,711 \\
0.503\end{array}$ \\
\hline
\end{tabular}

Notes: Endogenous variable is log of land value (LV) in RM/sqm in all models. Standard errors (in parenthesis) are heteroscedasticity robust. * denotes significance at the $10 \%$ level, ${ }^{* *}$ denotes significance at the $5 \%$ level and ${ }^{* * *}$ denotes significance at the $1 \%$ level.

\section{Changes in CBD-Accessibility and Land Values}

\subsection{Marginal Value of Travel Time Reduction}

Results presented in the sections above suggest a positive impact of reduced travel time to the CBD since the flattening land gradient found on the basis of straight line distances was not accompanied by a respective change in travel time gradient. Over the course of our observation period, we would therefore expect an increase in land values particularly at those locations that experienced major reduction in travel time. We employ an approach similar to GIBBONS \& MACHIN (2005) in order to reveal the marginal impact of travel time reduction on the value of urban land. Starting from equation (1) we replace distance to CBD by travel time to CBD (ttCBD) and allow for unobserved fixed location effects $(f)$.

$\log \left(L V_{i t}\right)=\alpha_{t}-\beta t t C B D_{i t}+f_{i}+\varepsilon_{t i}$

Assuming that the marginal benefit of travel time does not change over time, in time-difference form we obtain:

$\log \left(L V_{i t}\right)-\log \left(L V_{i t-1}\right)=\left(\alpha_{t}-\alpha_{t-1}\right)-\beta\left(t t C B D_{i t}-t t C B D_{i t-1}\right)+\left(\varepsilon_{t i}-\varepsilon_{t-1}\right)$

where $t$ refers to 1936 and $t-1$ to 1890 . 
In contrast to the travel time gradient models estimated in the section above, this specification controls for unobserved time-invariant location characteristics, assuming that marginal price effects remain constant. Column (1) of Table 8 shows a time-difference estimate corresponding to equation (5). The marginal increase in land value of $13.5 \%$ for a one-minute reduction of travel time to the CBD (1) fits exactly into the range of cross-sectional OLS results presented in Table 5.

Tab. 8 Marginal Value of Travel Time

\begin{tabular}{cccc}
\hline \hline & $(1)$ & $(2)$ & $(3)$ \\
\hline \multirow{2}{*}{$\alpha_{t}-\alpha_{t-1}$} & $-0.126^{* * *}$ & $5.866^{* * *}$ & $5.870^{* * *}$ \\
$\beta$ & $(0.0394)$ & $(0.3000)$ & $(0.311)$ \\
& $0.135^{* * *}$ & $0.104^{* * *}$ & $0.105^{* * *}$ \\
X-Coordinate $(\mathrm{km})$ & $(0.0071)$ & $(0.0065)$ & $(0.0066)$ \\
$\gamma$-Coordinate $(\mathrm{km})$ & & $-0.157^{* * *}$ & $-0.156^{* * *}$ \\
KUarea & & $(0.0087)$ & $(0.0091)$ \\
& & $-0.114^{* * *}$ & $-0.115^{* * *}$ \\
KUarea x distKU & & $(0.0111)$ & $(0.0112)$ \\
Obs. & & & $0.950^{* * *}$ \\
$\mathrm{R}^{2}$ & & & $(0.1600)$ \\
& 1,478 & & $-1.520^{* * *}$ \\
& 0.197 & 1,478 & $(0.225)$ \\
& & 0.429 & 1,478 \\
\end{tabular}

Notes: Endogenous variable is log-difference between land values 1936 and 1980. Standard errors (in parenthesis) are heteroscedasticity robust. * denotes significance at the $10 \%$ level, ${ }^{* *}$ denotes significance at the $5 \%$ level and ${ }^{* * *}$ denotes significance at the $1 \%$ level.

However, at least two major changes in the spatial structure of the city deserve closer attention. In line with anecdotic evidence, section 2 results suggested a significant increase in land values in the west and south of Berlin during our observation period. Since this shift in location desirability may be attributable to other factors besides the improved accessibility by rapid transit lines, we introduce $X$ - and Y-coordinates as location controls in models (2) of Table 8. While the coefficients on coordinates show the expected signs, the marginal value of reduced travel time to the CBD is somewhat reduced, however still exceeding $10 \%$ per saved minute for the journey to the CBD.

Figure 4 illustrates the emergence of the area around Breitscheidplatz and Kurfürstendamm as a dense cluster of economic activity during our study period. 
Since the new business agglomeration itself probably became an autonomous source of production externalities, we further extend the model in order to allow for a local increase in the marginal value of proximity to the respective area (column 3). The coefficient on KUarea, a dummy denoting areas within a $1000 \mathrm{~m}$ radius from Breitscheidplatz, indicates a relative increase in land values up to approximately $159 \%{ }^{17}$ As suggested by the coefficient on the interactive term between KUarea and distance to Breitscheidplatz (distKU), the effect diminishes with distance and disappears after $1 \mathrm{~km}$ or so. ${ }^{18}$ These results confirm the conventional wisdom on the emergence of a strong sub-center at the location which is today known under the label "City-West". At the same time, the estimate on marginal value of travel time saving remains almost unaffected, even slightly increasing to $10.5 \%$. This value notably falls within the range of cross-sectional SAR estimates presented in section 4 .

\section{Fig. 4 Change in Land Value 1890 - 1936}

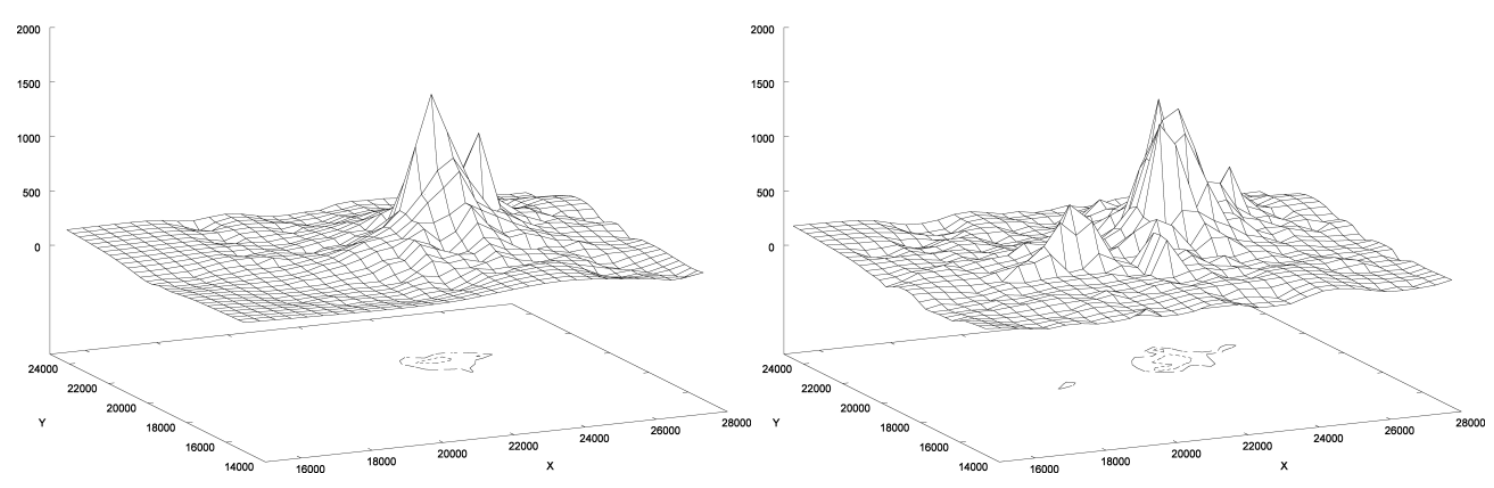

Notes: Coordinates refer to the Soldner System defined by the Senate Department. The west peak of 1936 data refers to the emerging center of the Kurfürstendamm.

\subsection{Counterfactual Scenario}

As discussed, several factors such as city growth, increasing demand for industrial land, or changes in production technology potentially influence the evolution of land gradient over time. These effects are difficult to separate, in particular since some of the driving forces point to opposite directions. Our results so far suggest

17 According to HALVORSEN \& PALMOUUIST (1980), the percentage impact in semi-log models corresponding to a parameter estimate $b$ may be approximated by $(\exp (b)-1)^{*} 100$.

${ }_{18}$ Both Akaike and Schwarz criteria as well as adjusted $\mathrm{R}^{2}$ reject alternative specifications $(500 \mathrm{~m}$, $1.5 \mathrm{~km}, 2 \mathrm{~km}$ ) in favor of the $1 \mathrm{~km}$ model. 
a significant effect of reduction in implicit transport cost to the CBD on the value of urban land as it is predicted by the monocentric city model. Therefore, the connection of peripheral urban areas to a system of rapid mass transportation obviously exhibits a price appreciating effect. But to which extent did the fundamental change in accessibility observed during our study period promote decentralization of economic activity? We address this question by asking what would have happened in a counterfactual scenario without the construction of the new transport network.

Therefore we subtract the estimated price effect corresponding to the effective reduction in travel time between 1890 and 1936 from the 1936 log land values, using $\hat{\beta}$ from Table 8 , column (1) and (3).

$\log \left(L V_{i t}{ }^{c}\right)=\log \left(L V_{i t}\right)-\hat{\beta}\left(t t C B D_{i t}-t t C B D_{i t-1}\right)$

The counterfactual land values $(L V)$ are used for standard gradient estimates corresponding to equation (1). The resulting counterfactual gradient estimates indicate a decrease per $\mathrm{km}$ ranging from $52 \%$ to $56 \%$, depending on whether location control variables were considered in the baseline estimation or not. ${ }^{19}$ Hence, our counterfactual scenarios suggest that without the major improvements in transport infrastructure, the flattening of the land gradient would hardly have exceeded the effective 1896/1900 level. This finding is in line with cross-sectional travel time gradient estimates from section 4 , which do not show a systematic decrease after 1896.

As illustrated in Figure 5, effective reductions in travel times seem to account at least for about one half of the decentralization observed from 1890 to 1936 . On the other hand, transport innovations can not entirely explain the flattening of the land gradient during our observation period, although additional improvements beside the rapid transit lines may also have exhibited an important effect. After all, the common phenomenon of a flattening land gradient, in the case of

${ }_{19}$ Results table is provided in the appendix. 
Berlin, seems to be attributable to a combination of decreasing transport costs and increasing city size and demand for land by industries, which dominated the potentially agglomerating effect of the CBD transformation into a pure government and office district.

Fig. 5 Effective and Counterfactual Land Gradient 1936

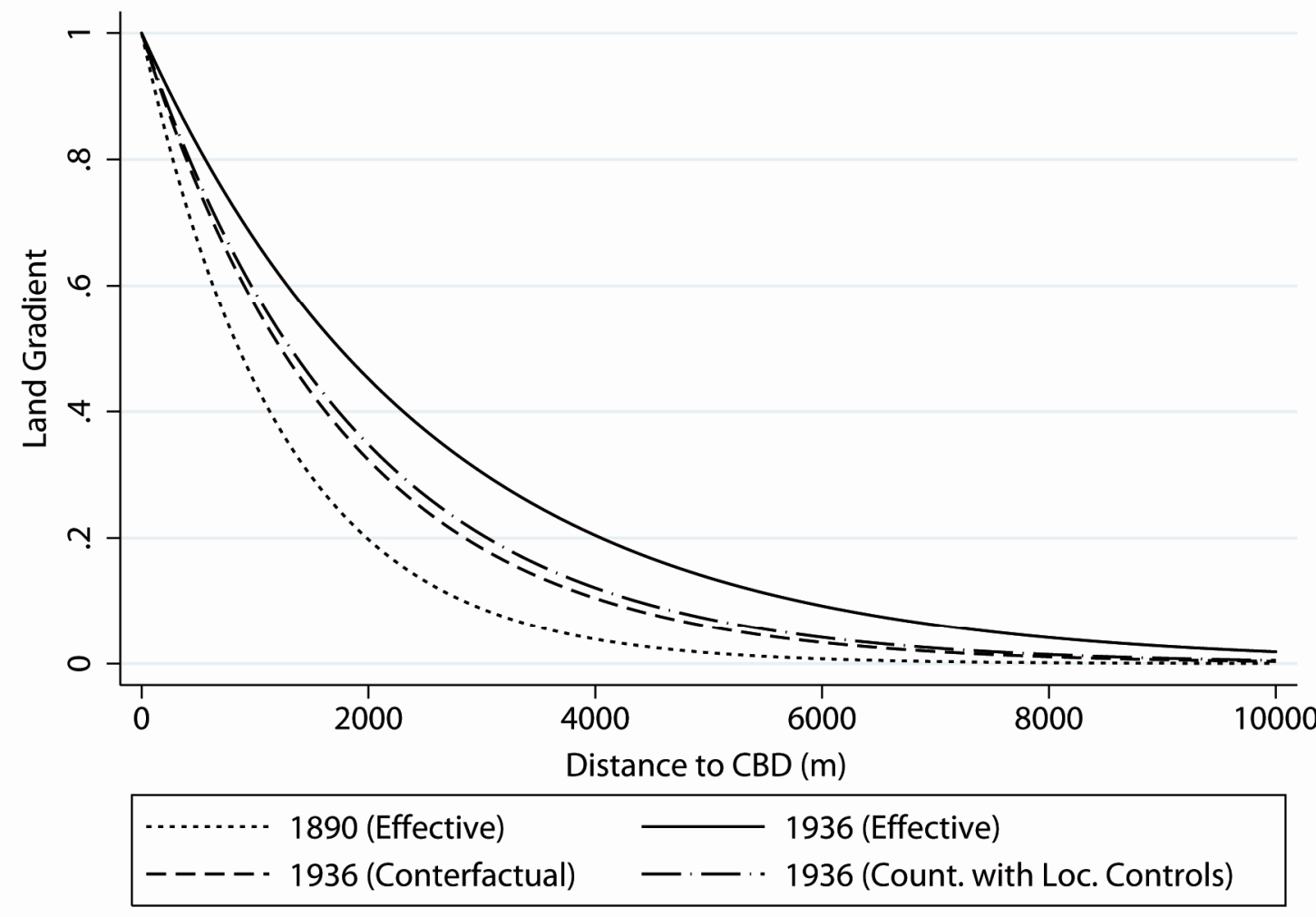

Notes: Figure illustrates gradient estimates from Table 1 and Table 8.

\section{Discussion}

Our results point clearly to a flattening land gradient by 1936 suggesting rising attractiveness for peripheral business locations. Simultaneously, a quite constant travel time gradient indicates transport innovations, which led to constantly decreasing travel times and the possibility to locate further from the center without losing the privilege of good accessibility. This section aims at placing our empirical analysis within the anecdotic deliverances conveyed by historians.

During the first half of the $19^{\text {th }}$ century, Berlin had already experienced enormous economic growth accompanied by huge population gains. In anticipation of fur- 
ther development, planning authorities decided to widen and completely restructure large parts of the city, even including surrounding communities and towns. The so-called Hobrecht-Plan was implemented in 1862 and should have lead to far-reaching building and reorganization processes by 1914 (HEGEMANN, 1930). By 1890 , the inner core was characterized by an enormous density of both, residential and commercial use. The recently generated and constantly increasing demand for a work force drew immigrants into those boroughs that only a few years earlier had still belonged to the city fringe. By that time, however, they already belonged to the inner parts of a fast-growing bigger region. ${ }^{20}$ Expanding administrative, financial, and manufacturing sectors (see section 2) created more and more need for land intensifying density within the historical CBD (HOFMEISTER, 1990; LEYDEN, 1933; LOUIS, 1936). The building activities of the Hobrechtplan facilitated some major movements. It created residential space combined with a well-planned concept of mixed use development. Especially along the representative boulevards, which in many cases led radially away from or in circles around the old CBD, large proportions were dedicated to commercial areas. These efforts consequently facilitated residential decentralization and a redistribution of market opportunities for businesses.

In particular, the south-western cities (and later boroughs of Berlin) Charlottenburg and Wilmersdorf experienced an enormous population growth between 1880 and 1910 and were characterized by their large proportions of wealthy inhabitants. ${ }^{21}$ The high concentration of purchasing power generated market potential, attracted economic activity and may have contributed in large to the emergence of the most important subcenter during this time. ${ }^{22}$ Indeed, our results

20 Up until 1912, Berlin was still represented by a relatively small area of $59.2 \mathrm{~km}^{2}$. Due to fast growth processes, it was expanding towards the outer boroughs. Simultaneously, the sur-

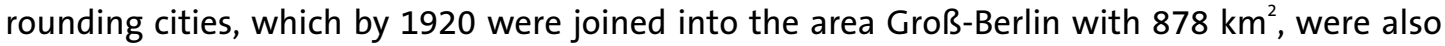
growing and expanding towards the old Berlin, completely enclosing its outer boroughs.

${ }^{21}$ During this period, Charlottenburg grew from 30,562 to 305,978 and Wilmersdorf from 2,911 to 109,716 inhabitants (LEYDEN, 1933).

${ }^{22}$ We refer to the abovementioned area around Breitscheidplatz along the Tauentzienstrasse and the Kurfürstendamm. 
from Tables 3, 7 and 8 show that areas to the south and west of the historical CBD exhibited an increasing attractiveness for commercial use.

Besides the planned initiatives for urban reorganization, the main inner city transport network was developed within the same period (see section 2) and most probably helped accelerating formulated intentions. The long radial railways connected even further communities to the inner regions of Berlin. This generated big incentives especially for wealthy residents, to settle in less central areas. Small settlements around and along the newly built lines and stations developed quickly and, naturally, also attracted business to some extent. This indicates that improving transport systems constitute a part - but not everything - in explaining decentralization processes. The history matches our counterfactual scenarios, which attribute about 50\% to urban railway development (Figure 5). The remaining effects probably adhere to urban policies, the general growth paths, and subsequently shifting market potential within the industrializing city.

\section{Conclusion}

In this study we provide evidence for the validity of the monocentric city model in Berlin, Germany, from 1890 to 1936 using an archival land value data set, which so far is unique for Europe. In line with existing evidence, our univariate gradient models point to a land gradient, that with respect to distance to the CBD flattens over time, accompanied by a considerably decline in model fit. However, by addressing spatial dependency in the data, we show that during our observation period, the monocentric model did not become fundamentally unsuited to describe the basic structure of the city, but instead other more localized location amenities are likely to have become more important. Our gradient estimates ranging from $\mathbf{7 7 . 5 \%}$ to $39.7 \%$ per $\mathrm{km}$ indicate relatively steep gradient decay compared to U.S. cities during the same period. This finding reveals a highly concentrated business agglomeration that hardly exceeded the boundaries of a relatively small historic city district; a phenomenon which could be typical for cities with a long history. Persistency of historic city structures is also indicated by the relatively stable location of the city's center of gravity. Similar research on histori- 
cally grown city structures would definitely lead to a more profound understanding.

We add to the literature by modeling effective travel times, taking into account development of rapid transit network, which reshaped the pattern of accessibility substantially over the course of our observation period. Our estimates indicate a marginal benefit of reduction in travel time to the CBD ranging between $10.5 \%$ and $13.5 \%$ per minute. These findings are consistently found in cross-sectional as well as time-difference estimates. Compared to the evolution of land gradient with respect to distance, trends in travel time gradients are much less precise, suggesting that peripheral locations experienced a rise in attractiveness as the connections to the center was improved. Particularly for the south west, there is evidence that a considerable increase in land values was preceded by fundamental improvements in accessibility. The importance of the rapid transit network for the spatial structure of the city is also highlighted by our counterfactual estimates which indicate that the land gradient would have declined considerably less if a new transport infrastructure had not been developed.

After all, our results support the monocentric model not only on the basis of the static comparison of land value and distance to the center, but also from a dynamic perspective. Variation in transport costs due to improvements in infrastructure is counterbalanced by an adjustment in land value as would be predicted by theory. However, while reduced transport costs essentially promoted decentralization during the observation period, other factors such as increasing demand for industrial land, city growth, and urban development policies certainly also contributed to the effective flattening of the land gradient. 


\section{Appendix}

Tab. A1 Counterfactual Land Gradient Estimates

\begin{tabular}{ccc}
\hline \hline & $(1)$ & $(2)$ \\
\hline$\alpha$ & $6.087^{* * *}$ & $6.097^{* * *}$ \\
$\beta$ & $(0.0488)$ & $(0.0469)$ \\
& $0.564^{* * *}$ & $0.528^{* * *}$ \\
Obs. & $(0.0138)$ & $(0.130)$ \\
$\mathrm{R}^{2}$ & 1,711 & 1,711 \\
\hline
\end{tabular}

Notes: Endogenous variable is counterfactual land value 1936 as defined in equation 6 in both models. Model (1) is based on $\hat{\beta}$ estimate from Table 8 , column (1), model (2) the respective estimate from column (3). Standard errors (in parenthesis) are heteroscedasticity robust. ${ }^{*}$ denotes significance at the $10 \%$ level, ${ }^{* *}$ denotes significance at the $5 \%$ level and ${ }^{* * *}$ denotes significance at the $1 \%$ level. 


\section{Literature}

ABELSON, P. (1997). House and Land Prices in Sydney from 1931 to 1989. Urban Studies, 9, 1381-1400.

ALONSO, W. (1964). Location and Land Use: Toward a General Theory of Land Rent. Cambridge, Massachusetts: Harvard University Press.

ANSELIN, L. (1988). Spatial Econometrics: Methods and Models. Dordrecht: Kluwer.

ANSELIN, L. (2003). Spatial Externalities. International Regional Science Review, 26(2), 147.

ANSELIN, L., \& BERA, A. K. (1996). Simple Diagnostic Tests for Spatial Dependence. Regional Science \& Urban Economics, 26(1), 77.

ANSELIN, L., \& BERA, A. K. (1998). Spatial Dependency in Linear Regression Models with an Introduction to Spatial Econometrics. In A. ULLAH \& D. E. GILES (Eds.), Handbook of Applied Economic Statistics (pp. 237-289). New York: Marcel Dekker.

ANSELIN, L., \& FLORAX, R. J. G. M. (1996). Small Sample Properties of Tests for Spatial Dependency in Regression Models: Some Further Results. In L. ANSELIN \& R. J. G. M. FLORAX (Eds.), New Directions in Spatial Econometrics (pp. 21-74). Berlin: Springer.

ATACK, J., \& MARGO, R. A. (1998). Location, Location, Location! The Price Gradient for Vacant Urban Land: New York, 1835 to 1900. Journal of Real Estate Finance \& Economics, 16(2), 151-172.

AUST, B. (Cartographer). (1986). Die städtebauliche Entwicklung Berlins.

BEDNARZ, R. S. (1975). The Effect of Air Pollution on Property Value in Chicago. Chicago: University of Chicago Press.

BEIER, K. (1990). S-Bahn Berlin. Der neue Triebzug et 480. Darmstadt: Hestra-Verlag.

BERRY, B. J. L. (1976). Ghetto Expansion and Single-Family Housing Prices. Journal of Urban Economics, 3(4), 397.

BLEY, P. (2003). Berliner S-Bahn. Düsseldorf: Alba-Verlag.

BORCHERT, F., STARCK, T., GÖTZ, G., \& MÜLLER, H. (1987). Berlin und seine S-Bahn. Berlin: transpress VEB Verlag für Verkehrswesen.

BORUKHOV, E., \& HOCHMAN, O. (1977). Optimum and Market Equilibrium in a Model of a City without a Predetemined Center. Environment and Planning A, 9(8), 849-856.

DITTFURTH, U. (1993). Strecke ohne Ende. Die Berliner Ringbahn. Berlin: GVE.

ELKINS, T. H., \& HOFMEISTER, B. (1988). Berlin: The Spatial Structure of a Divided City. London: Methuen.

FUJITA, M., \& OGAWA, H. (1982). Multiple Equilibria and Structural Transition of NonMonocentric Urban Configurations. Regional Science and Urban Economics, 12(2), 161-196.

GIBBONS, S., \& MACHIN, S. (2005). Valuing Rail Access Using Transport Innovations. Journal of Urban Economics, 57(1), 148-169.

HALVORSEN, R., \& PALMQUIST, R. (1980). The Interpretation of Dummy Variables in Semilogarithmic Equations. American Economic Review, 70(3), 474-475. 
HEGEMANN, W. (1930). 1930 - Das steinerne Berlin. Geschichte der grössten Mietskasernenstadt der Welt (Vol. 3). G. Kiepenheuer: Berlin.

HOFFMANN-AXTHELM, D. (1982). Einige historische Voraussetzungen Der Eisenbahnstadt. Berlin: Ästhetik und Kommunikation.

HOFMEISTER, B. (1990). Berlin (West). Eine geographische Strukturanalyse der zwölf westlichen Bezirke. Darmstadt: Wissenschaftliche Buchgesellschaft.

HOYT, H. (1933). One Hundred Years of Land Values in Chicago. Chicago: University of Chicago Press.

KALWEIT, F. (1928). Die Baustellenwerte in Berlin. Berlin: Ermo Verlagsgesellschaft.

KALWEIT, F. (1936). Die Baustellenwerte in Berlin. Berlin: Carl Heymanns Verlag.

KAU, J. B., \& SIRMANS, C. F. (1979). Urban Land Value Functions and the Price Elasticity of Demand for Housing. Journal of Urban Economics, 6(1), 112.

LEYDEN, F. (1933). Groß-Berlin. Geographie der Weltstadt. Breslau.

LOUIS, H. (1936). Die geographische Gliederung von Groß-Berlin. Stuttgart: Engelhorns Nachf.

LUCAS, R. E., JR. (2001). Externalities and Cities. Review of Economic Dynamics, 4(2), 245274.

LUCAS, R. E., JR., \& ROSSI-HANSBERG, E. (2002). On the Internal Structure of Cities. Econometrica, 70(4), 1445-1476.

MCDONALD, J. F. (1981). Spatial Patterns of Business Land Values in Chicago. Urban Geographie, 3, 201-215.

MCDONALD, J. F., \& BOWMAN, H. W. (1979). Land Value Functions: A Reevaluation. Journal of Urban Economics, 6(1), 25-41.

MCDONALD, J. F., \& MCMILLEN, D. P. (1990). Employment Subcenters and Land Values in a Polycentric Urban Area: The Case of Chicago. Environment and Planning A, 22(5), 1561-1574.

MCMILLEN, D. P. (1979). Economic Analysis of an Urban Housing Market. New York: Academic Press.

MCMILLEN, D. P. (1990). Consistent Estimation of the Urban Land Value Function. Journal of Urban Economics, 27(3), 285-293.

MCMILLEN, D. P. (1996). One Hundred Fifty Years of Land Values in Chicago: A Nonparametric Approach. Journal of Urban Economics, 40(1), 100-124.

MCMILLEN, D. P., JARMIN, R., \& THORSNES, P. (1992). Selection Bias and Land Development in the Monocentric City Model. Journal of Urban Economics, 31(3), 273-284.

MCMILLEN, D. P., \& MCDONALD, J. F. (1991). Urban Land Value Functions with Endogenous Zoning. Journal of Urban Economics, 29(1), 14-27.

MILLS, E. S. (1969). The Value of Urban Land. In H. PERLOFF (Ed.), The Quality of Urban Environment. Baltimore, MA: Resources for the Future, Inc.

MÜLLER, G. (Cartographer). (1881-1910). Karte zur Berechnung des Grund- Und Bodenwerthes in Berlin

MUTH, R. F. (1969). Cities and Housing: The Spatial Pattern of Urban Residential Land Use. Chicago: University of Chicago Press. 
PLAUT, P. O., \& PLAUT, S. E. (1998). Endogenous Identification of Multiple Housing Price Centers in Metropolitan Areas. Journal of Housing Economics, 7(3), 193-217.

RUNGE, E. (Cartographer). (1950). Bodenwertkarte Gross-Berlin (1938)

SMITH, F. H. (2003). Historical Evidence on the Monocentric Urban Model: A Case Study of Cleveland, 1915-1980. Applied Economics Letters, 10(11), 729.

TEN RAA, T. (1984). The Distribution Apprach to Spatial Economics. Journal of Regional Science, 24(1), 105-117.

VON THÜNEN, J. H. (1826). Der Isolierte Staat in Beziehung Auf Landwirtschaft Und Nationalökonomie, Oder Untersuchungen Über Den Einfluss, Den Die Getreidepreise, Der Reichtum Des Bodens Und Die Abgaben Auf Ackerbau Ausüben. Hamburg: Perthes.

YEATES, M. H. (1965). Some Factors Affecting the Spatial Distribution of Chicago Land Values, 1910-1960. Economic Geography, 41(1), 57-70. 


\section{Hamburg Contemporary Economic Discussions}

(Download: http://www.uni-hamburg.de/economicpolicy/discussions.html)

01/2005 FEDDERSEN, A. / MAENNIG, W.: Trends in Competitive Balance: Is there Evidence for Growing Imbalance in Professional Sport Leagues?, January 2005.

02/2005 SIEVERS, T.: Information-driven Clustering - An Alternative to the Knowledge Spillover Story, February 2005.

03/2005 SIEVERS, T.: A Vector-based Approach to Modeling Knowledge in Economics, February 2005.

04/2005 BUETTNER, N. / MAENNIG, W. / MENSSEN, M.: Zur Ableitung einfacher Multiplikatoren für die Planung von Infrastrukturkosten anhand der Aufwendungen für Sportstätten - eine Untersuchung anhand der Fußball-WM 2006, May 2005.

01/2006 FEDDERSEN, A.: Economic Consequences of the UEFA Champions League for National Championships - The Case of Germany, May 2006.

02/2006 FEDDERSEN, A.: Measuring Between-season Competitive Balance with Markov Chains, July 2006.

03/2006 FEDDERSEN, A. / VÖPEL, H.: Staatliche Hilfen für Profifußballclubs in finanziellen Notlagen? - Die Kommunen im Konflikt zwischen Imageeffekten und Moral-Hazard-Problemen, September 2006.

04/2006 MAENNIG, W. / SCHWARTHOFF, F.: Stadium Architecture and Regional Economic Development: International Experience and the Plans of Durban, October 2006. 


\section{Hamburg Contemporary Economic Discussions}

(Download: http://www.uni-hamburg.de/economicpolicy/discussions.html)

01

02

03

04

05

06

07

08

O9

10

11

12

13

AHLFELDT, G. / MAENNIG, W.: The Role of Architecture on Urban Revitalization: The Case of "Olympic Arenas" in Berlin-Prenzlauer Berg, 2007.

FEDDERSEN, A. / MAENNIG, W. / ZIMMERMANN, P.: How to Win the Olympic Games - The Empirics of Key Success Factors of Olympic Bids, 2007.

AHLFELDT, G. / MAENNIG, W.: The Impact of Sports Arenas on Land Values: Evidence from Berlin, 2007.

DU PLESSIS, S. / MAENNIG, W.: World Cup 2010: South African Economic Perspectives and Policy Challenges Informed by the Experience of Germany 2006, 2007.

HEYNE, M. / MAENNIG, W. / SUESSMUTH, B.: Mega-sporting Events as Experience Goods, 2007.

DUST, L. I MAENNIG, W.: Shrinking and Growing Metropolitan Areas - Asymmetric Real Estate Price Reactions? The Case of German Single-family Houses, 2007.

JASMAND, S. / MAENNIG, W.: Regional Income and Employment Effects of the 1972 Munich Olympic Summer Games, 2007.

HAGN, F. / MAENNIG W.: Labour Market Effects of the 2006 Soccer World Cup in Germany, 2007.

HAGN, F. / MAENNIG, W.: Employment Effects of the World Cup 1974 in Germany.

MAENNIG, W.: One Year Later: A Re-appraisal of the Economics of the 2006 Soccer World Cup, 2007.

AHLFELDT, G., MAENNIG, W.: Assessing External Effects of City Airports: Land Values in Berlin, 2007.

AHLFELDT, G.: If Alonso was Right: Accessibility as Determinant for Attractiveness of Urban Location, 2007.

AHLFELDT, G.: A New Central Station for a Unified City: Predicting Impact on Property Prices for Urban Railway Network Extension, 2007. 


\section{Hamburg Contemporary Economic Discussions}

(Download: http://www.uni-hamburg.de/economicpolicy/discussions.html)

FEDDERSEN, A. / MAENNIG, W.: Arenas vs. Multifunctional Stadia Which Do Spectators Prefer?, 2007.

AHLFELDT, G. / FEDDERSEN, A.: Geography of a Sports Metropolis, 2007.

FEDDERSEN, A. / GRÖTZINGER, A. / MAENNIG, W.: New Stadia and Regional Economic Development - Evidence from FIFA World Cup 2006 Stadia, 2008.

AHLFELDT, G. / MAENNIG, W.: Monumental Protection: Internal and External Price Effects, 2008.

MAENNIG, W. / PORSCHE, M.: The Feel-good Effect at Mega Sport Events - Recommendations for Public and Private Administration Informed by the Experience of the FIFA World Cup 2006, 2008.

AHLFELDT, G.: The Train has Left the Station: Real Estate Price Effects of Mainline Realignment in Berlin, 2008.

MAENNIG, W. / WELLBROCK, C.-M.: Sozio-ökonomische Schätzungen Olympischer Medaillengewinne: Analyse-, Prognose- und Benchmarkmöglichkeiten, 2008.

MAENNIG, W. / ALLERMS, S.: South Africa 2010: Economic Scope and Limits, 2008.

AHLFELDT, G. / FEDDERSEN, A.: Determinants of Spatial Weights in Spatial Wage Equations: A Sensitivity Analysis, 2008.

AHLFELDT, G. / WENDLAND, N.: Fifty Years of Urban Accessibility: The Impact of Urban Railway Network on the Land Gradient in Industrializing Berlin, 2008. 


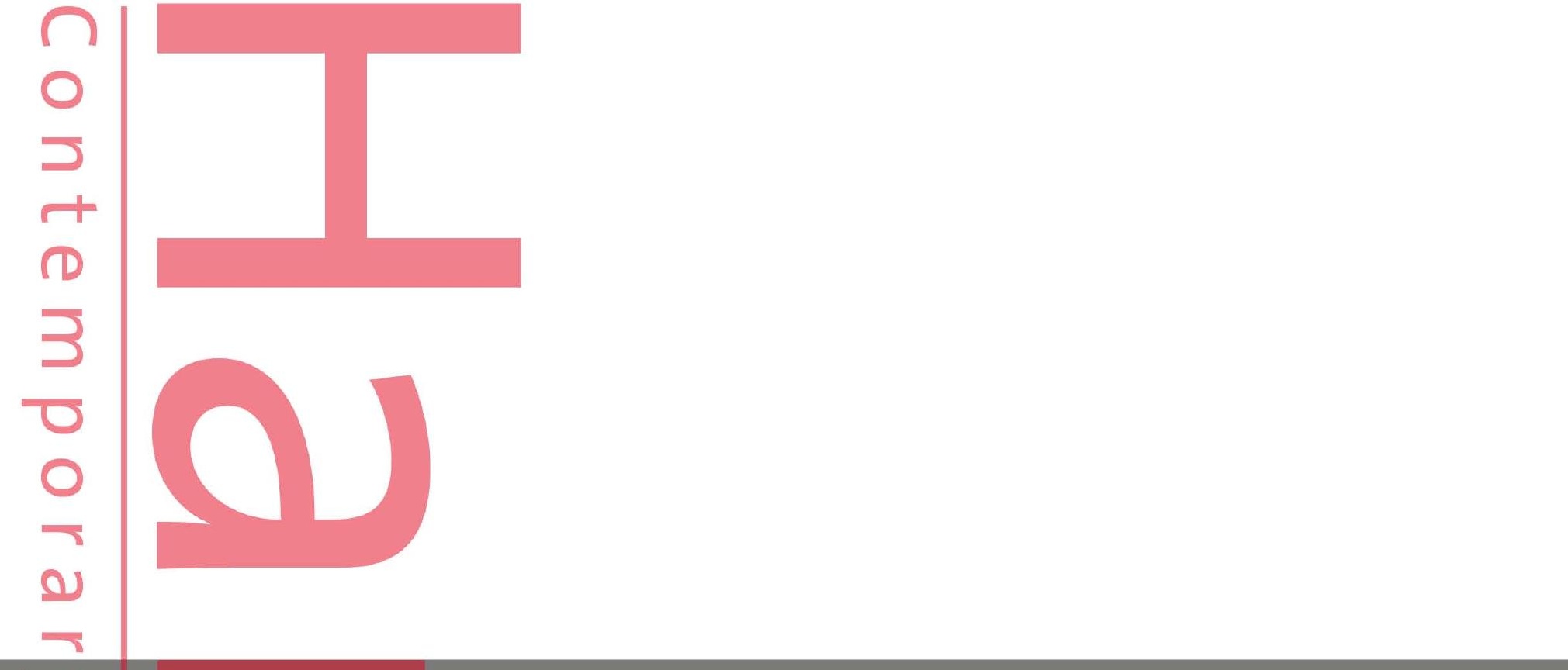

ISSN 1865-2441 (PRINT) ISSN 1865-7133 (ONLINE)

ISBN 978-3-940369-60-4 (PRINT) ISBN 978-3-940369-61-1 (ONLINE) 